This is a self-archived version of an original article. This version may differ from the original in pagination and typographic details.

Author(s): Saresma, Tuija

Title: Mohsen Emadi : A Poet of Exile

Year: 2019

Version: Published version

Copyright: (c) The Author \& Trames, 2019.

Rights: $C C$ BY-NC 4.0

Rights url: https://creativecommons.org/licenses/by-nc/4.0/

Please cite the original version:

Saresma, T. (2019). Mohsen Emadi : A Poet of Exile. Trames : A Journal of the Humanities and Social Sciences, 23(2), 203-221. https://doi.org/10.3176/tr.2019.2.06 


\title{
MOHSEN EMADI - A POET OF EXILE
}

\section{Tuija Saresma}

\author{
University of Jyväskyla
}

\begin{abstract}
I'm from exile". This is how a poet, a cosmopolitan, and a citizen of the world of poetry Mohsen Emadi describes himself. He writes poems on loss and displacement, charting his experiences of mobility. This essay is based on Emadi's poems and biographical interviews with the poet. Quotes from the interviews and fragments of his poems are combined with theoretical reflections on diaspora, nomadism, and exile by researchers such as Edward Said and Rogers Brubaker. Following Emadi, I take a critical look at the concept of diaspora and discuss mobility and exile both as a forced condition and as a choice. The experiences of both voluntary and coerced mobility are considered from the perspective of an individual within the context of global mobility. I suggest that via his writing, which draws from his personal experiences of mobility and non-belonging, Emadi himself becomes a poet of exile.
\end{abstract}

Keywords: belonging, biographical interview, diaspora, displacement, exile, mobility, nomadism, poetry

DOI: https://doi.org/10.3176/tr.2019.2.06

\author{
So unreachable am I \\ that only love or death \\ can take me out of my orbit. \\ I revolve around $a$ word \\ that empties other words. \\ My four seasons \\ are all one season: \\ exile \\ (from Mohsen Emadi's collection \\ "Standing on Earth", 2016:67)
}

\section{Introduction}

If the award-winning poet and translator Mohsen Emadi is asked, "Where are you from?", he will answer, "I'm from exile". Born in a small village in northern 
Iran, Emadi first moved to the capital city of Tehran without knowing that he was embarking on a life-long journey. After the election of 2009, political reasons forced him to leave the country. Since then, he has lived in Finland, the Czech Republic, and Spain, and is currently based in Mexico, splitting his time between Mexico City, where he conducts a doctoral research on digital poetry at UNAM, and Malincalo, where he collaborates on several cultural projects. Collections of his poems have been published in Iran and Spain. He also translates poetry (Interview with Emadi, see footnote 3; Saresma 2019).

A cosmopolitan, an exile, and a citizen of the world of poetry for whom "the world is home" (Davison and Muppidi 2011:5), Emadi writes poems on loss and displacement, charting his experiences of mobility as "someone who goes to bed in one city and wakes up in another", as the author and his poetry are described on the back cover of the collection, Standing on Earth (2016), translated into English from the original Persian by Lyn Coffin.

This essay is based on Emadi's poems, published in the aforementioned collection, as well as a biographical interview I conducted with the poet in the spring of $2017^{1}$ and is combined with theoretical reflections on diaspora, nomadism, and exile by researchers such as Edward Said and Rogers Brubaker. My aim here is not to analyze Emadi's poems as such: this is not literary text analysis, but instead a hybrid, where I aim at creating a poetic-conceptual discussion, entangling Emadi's own words both from his poems and citing the interview, with theoretical ponderings on exile and diaspora. Instead of me having the last word by giving my interpretations about the poems, I wanted to let Emadi's words speak for themselves, trusting the reader to make the connections.

Following Emadi, I take a critical look on the concept of diaspora and discuss mobility and exile both as a forced condition and as a choice. Here, the experiences of both voluntary and coerced mobility are considered from the perspective of an individual within the context of global mobility. I will begin with a brief review of the concepts of exile, diaspora, mobility, and nomadism - all central to the life and career of Mohsen Emadi. After that, I will explore how he negotiates his experiences of exile through writing, thus adding another layer to the theoretical conversation on exile. The life story of the poet and his reflections are mediated with his own words, spiced with my interpretation and contextualization. The aim is to show how mobility, both forced and voluntary, are harnessed as a driving force of Mohsen Emadi's art.

The galaxy of farewell

does not have

any sun

(from Standing on Earth, 2016:52)

1 The current article relates to a text I wrote in Finnish about Emadi's chosen way of life, which I called the politics of dislocation, and about his poem Yamsa (Saresma 2019). The text foregrounds the experiences and reflections of living in exile and Emadi's musings on diaspora. In this essay, next to the quotes from the interviews with Emadi, his poems, published in Standing on Earth, are included as indented vignettes. 


\section{On concepts}

Edward Said (1994:402) has suggested that our age is characterized by the production of an unprecedented quantity of 'refugees, migrants, displaced persons, and exiles'. This gives urgency to the exploration of both the experiences of the processes producing displacement and the concepts themselves.

First of all, the experiences of mobile people vary according to their position in the webs of hierarchical power relations that include gender, class, ethnic background, racialization, geographical location of origin, and education (on the intersections of power of mobile people, see Saresma 2016). The stark difference between the 'optimistic mobility' shared by many intellectuals theorizing mobility and the "massive dislocations, waste, misery, and horrors endured in our century's migrations and mutilated lives" (Said 1994:403) must not be downplayed in research. Also, the situation appears to have only worsened after Said's comment. This has been the case especially after the events of 2015 when a record number of African and Middle Eastern people arrived in Europe seeking asylum. The media soon dubbed this the 'refugee crisis'. However, the crisis was first and foremost a European crisis, or Europe's border crisis (Vaughan-Williams 2015); the events were only framed as a crisis by right-wing populist actors once they reached the borders of Europe (Perälä and Niemi 2018).

Secondly, the concepts related to voluntary and forced migration are used in multiple and sometimes confusing ways. In what follows, I will briefly discuss the ways in which concepts such as exile, diaspora, and the nomad, are used in academic literature in order to preface the exploration of Mohsen Emadi's use of these concepts.

According to Andreas Hackl (2017:55), exile is "an ancient concept expressing a form of political banishment and the enduring consequences of forced displacement". As a form of punishment, an enforced expulsion from the natal community has always been about forced relocation (ibid.). As such, it has been considered a negative phenomenon. Said (2001:173) found it 'terrible to experience', while admitting that the idea of exile had a 'strangely compelling' character.

The figure of the migrant, for Said (1994:203), has the consciousness of "the intellectual and artist in exile, the political figure between domains, between forms, between homes, and between languages" and is the incarnation of "unhoused, decentered, and exilic energies". This somewhat idealistic definition betrays a certain undertone of admiration towards artistic and intellectual freedom that Said calls 'intellectual exile', although he does make a point of reminding us that he does not wish to liken 'the bravura performances' of the intellectual exile to "the miseries of the displaced person or refugee" (ibid.).

Indeed, it is not unusual for artists and intellectuals to be voluntarily dislocated, or to find themselves "geographically or linguistically 'out of place", as Olli Löytty (2018:71) states, continuing: "the list of writers in exile or writers who have voluntarily emigrated from their country of origin is long". This suggests that 
the experience of exile can be a fruitful ground for creativity, turning the dislocation into a potentially productive state.

The concept of refugee "entails a legal dimension and indicates impermanency", setting it apart from exile, which "features temporal depth and a concern with 'integration"' (Peteet 2007:633-636). The modern refugee, for Said (2001:181), "suggests an anonymous collective of 'innocent and bewildered people" whereas a modern nomad (Braidotti 2004) as always on the move, 'always becoming', is a transgressor that challenges state control and embodies freedom (Engebrightsen 2017).

Diaspora is a relatively new concept, having entered the social sciences lexicon only in the 1960s, "becoming an all-purpose word in the 1980s" (Dufoix 2008:19), and eventually replacing 'exile' in the media and scholarly discussion due to the influential theories of globalization and postmodernism (Hackl 2017:59). Originally, discussions on diaspora referred to a conceptual 'homeland', and the 'classical' diasporas were those of the Jews, Armenians, and Greeks (Brubaker 2006:2). Later, the term has also been used to refer to the African diaspora (Rastas 2014). Recent decades have witnessed an "explosion of interest in diasporas", Rogers Brubaker (2005:1) notes, and the meanings of the concept have dispersed accordingly. This has led to a situation where some emigrant groups have been called diasporas "because of their continued involvement in homeland politics", and the word is even used in reference to labor migrants who still have emotional and social ties with their homeland (Brubaker 2006:2).

The aforementioned usage of the concepts of diaspora and exile follows certain wider academic trends, but it is important to note that they also refer to different levels of social relations. As Hackl (2017:60) puts it, exile as "solitude outside the group" (Said 2001:177) differs essentially from "diaspora's 'groupness"” (Brubaker 2005:12). Exile, however, is not only a subjective experience in the sense that as a condition, it "links displaced subjectivity with larger political forces" (Hackl ibid.). Exile also "saturates classificatory terms such as 'refugee' or 'migration' with temporal depth, political agency and deeper subjective meaning" (ibid.).

Nomadism as a form of mobility differs from exile and diaspora in the sense that it does not require permanent dislocation, but includes recurrent traveling between certain places and temporary, yet repetitive movement. Nomadism is defined in Encyclopaedia Iranica as "a way of life and human existence that is connected with permanent and more or less regular movements of people between different locations" (Ehlers 2011). It is typical for nomads to follow "clearly defined routes" in moving between destinations, "pursuing their economic activities and ensuring their livelihood" (ibid.). The source of livelihood of pastoral nomads is domesticated animal husbandry and their migration is directed by "established routes between focal grazing areas". The nomadic way of life includes the "mobility of herds, people, and their habitats" (ibid.). The nomadic lifestyle in Iran is determined by the country's geography; the mountains and deserts and the distinctly arid climate have given rise to a special form of 
nomadism, namely 'mountain nomadism' or 'vertical nomadism'. Archaeological and anthropological evidence shows that various "forms of mobile and nomad-like pastoralism have been practiced in Iran's mountain belt since prehistorical times" (ibid.).

Sometimes, the concepts of exile, diaspora, and nomadism are also used interchangeably. In what follows, I will turn to the uses and understanding of the concepts by the poet Mohsen Emadi.

\section{Mohsen Emadi's mobile life}

I first met Mohsen Emadi at the University of Jyväskylä's Department of Music, Art, and Culture Studies where he worked in the spring of 2017 preparing a dissertation on digital culture. Having learned that he had led a mobile life, I was hoping that he would be willing to talk about his personal experiences of mobility and exile for my research project titled Intersecting Mobilities. ${ }^{2}$ Three interviews were conducted ${ }^{3}$ and during them, Emadi engaged himself with profound reflections on exile. Later, reading his poems convinced me that exile was indeed one of the central themes of his poetry.

At the beginning of the interview, Emadi posed the questions: "What causes mobility? What are the reasons of mobility?" and then explained his thoughts on the issue: "What forces a person to leave a place or makes them want to leave a place [---] is related to various aspects of life. There is a cultural dimension, there is a socio-political dimension, and there is a personal dimension to it." In this essay, these three levels will be discussed, starting with the cultural dimension. As Emadi explains, based on his own experiences, "there are cultures that have the experience of mobility inside them, for example nomadic cultures". According to Emadi nomads were never considered not to be inside the culture, unlike gypsies who are typically seen as outsiders. In Iran, the culture accepted the nomadic people as their own. They traveled between regions, depending on the season. In the winter they were in one place and in the summer, they were in a different place. Mostly, they walked with their sheep and cows.

Although Mohsen Emadi does not belong to nomads, he is familiar with nomadic cultures. Part of his family, on his mother's side, were nomads. Emadi was born in Iran in 1976 in a little village near Sari, the provincial capital of Mazandaran, the Northern province of Iran. The area is located between the Alborz Mountains and the Caspian Sea and its geography has produced a strong

2 See Intersecting Mobilities<http://www.intersectingmobilities.org/>.

3 Two of the three interviews were quite spontaneous and took place without preparing at the Jyväskylä city library. They were thus not recorded, and are used here as background material. Only the third interview - the longest and the most thorough one - that took place at the department of Music, Art, and Culture Studies, University of Jyväskylä, Educa Building on April 27, 2017, was taperecorded and transcribed. All the quotations in this article are from this interview. 
tradition of nomadic ways of life. Since Emadi has lived close to nomads, he has also family memories of them. He recalls of being very excited about the image of the nomadic people in his childhood because those people were not stuck in one place. "Sometimes, when something makes me feel stuck in a place, I identify with the nomads of my childhood." It was in his blood, it felt "natural' for Emadi to live a mobile life. His curiosity for the nomadic lifestyle started in his childhood and has followed him ever since.

\author{
We were always traveling, \\ and the place was one of three types: \\ the one that was becoming memory, \\ the one that was escaping from sight, \\ the one which fit in a suitcase. \\ Time interferes with memory, \\ The heart of dreams beat in a place that escaped. \\ The suitcase closes \\ and opens, \\ and one place mixes with another \\ (from "We Were Always Traveling”, Standing on Earth, 2016:45)
}

\title{
4. Separation from the family
}

The socio-political dimensions of mobility that Emadi mentions have to do with social instability. Iran was not a harmonious place to live in: the "factional bifurcation between the Liberal Left Reformists and the Religious Right Conservatives" that Emadi witnessed reveals "a larger political fragmentation and the gradual dissipation of the whole ideological foregrounding of the Islamic Revolution". It was "articulated in successive moments of critical crisis in modern Iranian history" as a site of ideological and religiously nativist resistance to colonialism and as a confrontation between Islam and the West (Dabashi 2011:57.). The Islamic revolution that transformed Iran from a monarchy under the rule of Shah Pahlavi to the theocratic Islamic republic of Ayatollah Khomeini took place in 1979. The social unrest related to the revolution casts a shadow over Emadi's youth, since he was born two years before the Islamic revolution. Later on, the civil war started. That and the war between Iran and Iraq (1980-1988) became the context for a big part of Emadi's early life. The stories of war have a profound meaning for him. After the religious fundamentalists took over, there was always the sense of instability and danger that eventually led to his exile.

The cultural and socio-political dimensions of mobility and exile intertwine with the more personal dimensions. Almost all of his life, Mohsen Emadi has felt estrangement from both his native country and his family, mostly because of the difficult relationship he has had with his father: "When I turned around thirteen, I started questioning my father. Before that, he was my hero. His was the dominant 
voice in the house. But I started questioning him." The strongest discord between the father and the son was caused by books.

Emadi's father was a powerful religious authority in the village, a learned man, a connoisseur of religious literature. But the books Emadi read, which were mostly secular, encouraged him to question his father. The consequence was disagreement and even physical violence, as the father could not bear to have his son turn against him. Although fierce, Emadi understands his father to some extent and forgives him his denunciation:

My father was not a bad person. He helped the anti-revolutionaries, antiIslamist people, he was not a governmental figure, never. Outside of the family, he was respected by anti-revolutionaries, anti-Islamists, even religious minorities, and was loved by them.

The violent behavior of Emadi's father is perhaps not unfathomable in the context of the inflammable political situation of Iran. According to Emadi the conflicts inside families started to rise when the civil war started, especially due to the political ideas. Emadi's uncle and his father became enemies although they had been close friends before the revolution. Emadi's mother had married his father because of the close friendship with his brother, Emadi's future uncle. "There was genuine trust and friendship between them, but after the revolution, two years later, they turned against each other."

Starting from then home becomes not really a good and safe place to live in, because it ceased to provideany security. Emadi recalls his father and mother constantly fighting with each other and how he was prohibited from meeting and playing with his cousins for about nine years. Emadi also remembers that there were rebels against the Islamists, mainly Marxists, who took shelter in the forest by their village. When there was a military confrontation, parts of Emadi's mother's side of the family had sympathy for the rebels and his father's side had sympathy for the regime.

This was when the families got separated. Family, which was supposed to give us security, did not feel safe anymore. This is a very strange experience, because you cannot identify with your father and your mother, who are fighting, so you do not identify with your family. You have to start, already in childhood, to define your own identity outside the context of the family.

Besides the cultural comprehension of nomadism, the entanglement of sociopolitical and personal hardships caused by the war marked the beginning of Mohsen Emadi's exile, which became more absorbing over the course of his life.

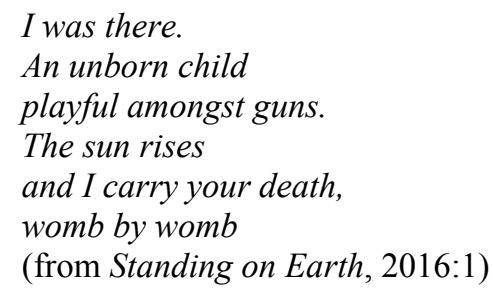




\title{
5. Rebellion, autoexile, exemption
}

Hamid Dabashi, a writer and intellectual born in Iran, suggests that "Iranians take poetry quite seriously - a habit that tends to lend a certain poetic diction to our historical recollections, the way we remember ourselves", even to the extent that Persian poetry "is the pulse of Iranian culture, the rhyme and rhythm of its collective memory" (Dabashi 2011:121-122). Emadi experienced the value of poetry and poets because of his talent. Young Mohsen was a popular and awardwinning poet. Before rebelling against his father, he was praised for his religious poems, and the beginning of the young poet's career was glorious. He was winning student poetry competitions all over the country and could consider himself a professional at the poetry festivals at that time. Emadi attended literature festivals since he was twelve and he got to know a vast group of poets who were his age or older, and shared the same ideologies. Back then Emadi was under the influence of classic Persian texts, mainly because of his grandfather and because of the interest of the government as well. It was normal to dislike contemporary and modern literature and be fond of traditional literature. Thus Emadi was writing sonnets.

Young Mohsen soon started seeing the narrow-mindedness and intolerance of the religious poetry elite of the country. This happened around the time he started reading secular literature. Besides the disagreement with his father, it also led to a political and personal awakening. At a literature festival in the northwest of Iran, in Tabriz young Mohsen fell in love for the first time and this was a moment of awakening for him. It was the first time for him to acknowledge the inner contradictions in himself, to let them come to the surface. He describes himself at the time as someone who had the Islamic face, with many contradictions inside. He recalls the experience of being and feeling controversial very vividly since he was acting like a religious person at the time and thus he was not looking at women. "I was keeping my distance, I was not listening to their voices. I was very careful, a very good Islamic boy, as they wanted me to be." Falling in love for the first time allowed the suppressed parts of himself to come to the surface:

\begin{abstract}
And there were these feelings in me, but they didn't have any meaning for me, because they had been suppressed. But [in Tabriz] I discovered my body, and I realized this, all these years after my childhood, that I had forgotten one simple thing: my body. So, there was sin emerging. But when love actually happens, it turns out that the sin is no sin after all. Sins are in fact pleasures, they are acts of rebellion, they have a meaning. They made it possible for me to give a different meaning to that simple event: A man looking at a woman and falling in love. It was the moment when I could bring out all these things inside me, to give in, to realize another dimension, to give it a different voice.
\end{abstract}

After the rebellion against his father, incited by the reading of secular literature, falling in love was the second step on Mohsen's route to exile, understood in a positive sense as freedom from the demands of religious conservatism. Through the love story Mohsen was able to free himself, the love story helped him to let the 
change happen in himself, to let it come to the surface. "The change came out that night through that one poem," he claims. Since then Emadi wrote entirely different type of poetry. From that moment, he was also expelled from poetry competitions, because his new poetry was a rare type of the poetry, it was closer to modern literature.

I kiss your fingertips.

I bury the cut heads

(from Standing on Earth, 2016:25)

This contemporary poetry excluded Emadi from traditional Iranian literature circles and brought him to a special kind of exile, exclusion from the community he had belonged to. Emadi remembers how the secretary of the education of northern Iran called his father and said, "Your son got lost. He is not praying at any of the festivals. He reads anti-revolutionary writing and talks about it, and his poetry is no longer the same. You must control him." The poetry society was pressuring Emadi's father and Emadi came to be under a horrible pressure to change his attitude. This does not brake him, but rather makes him stronger, since he feels the urgency of rebellion. He feels that he needs to stand against certain tendencies: "Reading translated [modern poetry] and reciting it was meaningful. And I felt that this is poetry; what [the authorities] promoted was not poetry. "But just like at home where his father abused him for reading secular literature, the poetry community punished him for writing secular poems:

I paid with my body, with lashings, with all the forms of condemnation. All this, [including] being expelled, instead of making me weak, connected me even more closely to poetry. And I felt that I had the meaning right there. So, I was exiled, kind of banished from many poetry societies, and from my own family.

He describes this as autoexile:

I started to kind of autoexile from the Iranian literary community. I didn't want to meet them; I was not going to their readings or where they were inviting me. I was mainly translating poetry and getting involved in some digital publications, several digital journals, including political digital journals, and literature I found at that time. So, I focused on my own project, but on an international level, or with an international dimension.

First, Mohsen Emadi rebelled against his father and then against the conservative poetry society, a rebellion linked to the experience of falling in love. This forced him to exile. But as he says, "exile, even though it was sad, was also very powerful and meaningful for me". In exile, he was following in the footsteps of an earlier generation of poets. When he left northern Iran and his family, he went to look for his hero, Ahmad Shamlou, the major Iranian poet of the last century, who was behind many anti-Islamic activities and was one of the main founders of the Iranian intellectuals movement against the Islamic republic in 1992. Emadi wanted to meet Shamlou in person, because "this passion inside me did not allow me to just read him". He wanted to meet him, to work with him, and to be in touch with the place from where the power of poetry came. 
And this autoexile opened up a new path for Emadi - that of the life of a writer, a poet.

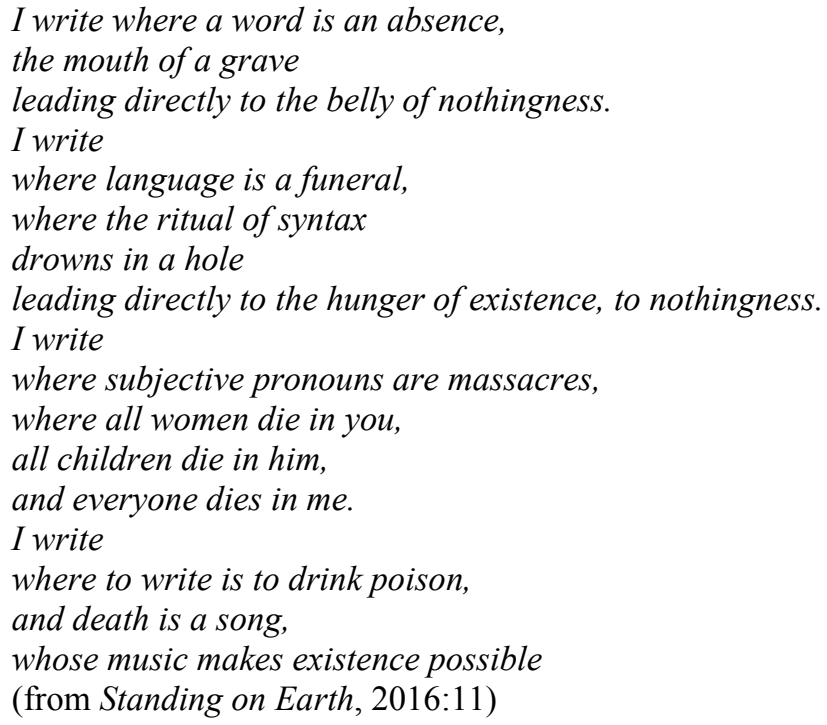

\section{Becoming expelled}

Exile often means leaving one's native country. Mohsen Emadi emphasizes instead that he feels estrangement at his home, at his village of birth, and later, in the societies of religious poets. He feels that he was already expelled in some ways while still living in Iran. He was shunned by the fanatic religious atmosphere and the "forceful nationalization of a polyfocal culture" that, as Said (1978) has it, fights the colonization of the Orientalä territories by Europeans, but simultaneously continues colonizing its minorities, such as the nomads (Dabashi 2011:127). For Emadi, however, Iran is not one culture. "There are different cultures. Several cultures, several languages live there." This disparity between the national discourse and Emadi's thought forced him into a 'proximate exile' (Peteet 2007, Hackl 2017:62), where exile is nothing exotic, but detachment of a community while still living in his native country.

Exile was a part of my life when I was in Iran.[---]From 19 to 21, I went to northern villages to find people who knew the folklore and legends [---]. I was particularly interested in love stories, fairytales, ballads, and stories about rebellion. [---] We also went to 166 Iranian villages to investigate migration between villages and cities. These two years of traveling allowed me to live a nomadic life.

After those years of nomadic life, Emadi moved to Tehran to study computer engineering at the Sharif University of Technology. At the time, he was also building a reputation as a poet and partaking in political activism, made possible 
by his rebellious background. Against this backdrop, Emadi's rebellious position towards the establishment can be interpreted as political activism that seeks justification from his nomadic bloodline. His studies were a neat cover for his activism and guaranteed him a certain level of independence from the state, just like the nomadic way of life had provided his ancestors with independence.

I was lucky because my job was in computers and not in journalism or the humanities. I made money independently of the government. So, I was doing my programming, earning my money, writing my poetry, and doing my translation without having to beg the government for money or grants. Many Iranian writers of my time had their background in the humanities or journalism and they had to shut up because the government was cutting their funding. But I did not need to; I was independent.

Around that time, Emadi started gaining reputation also outside of Iran, which enabled him to travel abroad: "In 2002, when my first publication came out in Spain and then in 2003, when the book appeared, I started to constantly visit Spain and split my time between Spain and Iran, going there for a few months and coming back, spending a few months there and then returning to Iran."

Economic freedom made it also possible to engage in political activism. This phase of Emadi's life is characterized by voluntary mobility, a certain form of nomadism where he commuted between Iran and Spain on a regular basis. Living a cosmopolitan life based on individual choice played its part in bolstering his international reputation as a poet. This could hardly have happened, had he stayed in Iran. But the political situation in the country intensified as the 2009 election brought about large protests in which president Ahmadinejad's re-election was hotly disputed. During the protests, which have been called 'the Iranian Green Movement', 'the Persian Awakening', or 'the Persian Spring', Emadi 'was fighting in the streets'; in the demonstrations, a thousand people were arrested and 20 were killed. It became clear that it was impossible for Emadi to continue living in Iran, even part-time: "In 2009 I realized that if I don't leave Iran, I will be persecuted. I left. I came to Finland. Then another stage of my life began."

Mohsen Emadi's life now begins to resemble that of people who have had to flee from their native countries. Liisa Malkki (1995:496) points out that even forced population movements (not to mention voluntary migration) involve people "who, while all displaced, find themselves in qualitatively different situations and predicaments". This becomes evident in Emadi's varying experiences of migration. At this point, no longer a cosmopolitan artist who is able to travel as much as he likes, his narrative reminds those of refugees and other less privileged migrants. As he himself didn't have any money, he learned something about forced mobility: "I am very grateful for the possibility to live the life of the people who bordered on being homeless. The very poor people. [---] There were days when I didn't have anything to eat. I was collecting cigarette butts to smoke. So, I have sympathy for alcoholics and the homeless. Because for a while I lived like them."

This temporary life in squalor, the concrete homelessness and poverty that Said (1994:400) would perhaps call "unhoused exilic experiences" in a metaphoric 
sense, also affected his poetry: "The poetry that I wrote at the time was very tragic." However, things got better, since he had the great luck of having good friends in Spain, in France, in Finland. Without their help, Emadi claims, he would not have survived. "I had my books, for example, in seven cities in Europe. I didn't have rent to pay, so I was moving from one friend's house to another friend's house. "His friends lived in different cities and paying for a bus ticket was for him cheaper than it would have been to pay rent.

When Emadi won a literary prize, he sees it as luck. "Had it happened three months later, I would have been dead, but it happened at that crucial moment." This unexpected financial support enabled him to recover from the experiences of homelessness as concrete poverty, as dependence of the charity of his friends, and as the inability to being able to take care of himself, and gave him trust in his talent as a writer. This is an example of how both voluntary and forced mobility, entangled with homelessness, functioned as a driving force of Emadi's art.

Despite having had to endure some difficult times, Emadi does not have any regrets about leaving Iran, and he is not going back either: "There was no other way for me. My father was calling, telling me to write an apologizing letter to the government and to do this and that and come back." His father told Emadi that he would still go to jail for a few years, but he will be able to come back to his country, if he is willing to apologize. Emadi felt that this would be giving up. But he is not the type who gives up, he would rather die than give up, as he states during the interview.

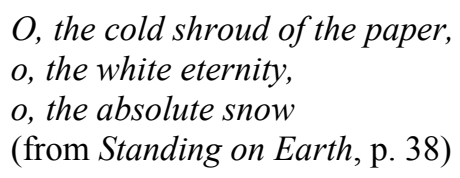

\section{Finland as exile}

Exile, both as a concept and an experience, is - with notable exceptions such as Said's (2001; see also Lumsden 1999) - understood as negative, a punishment or a loss. For Mohsen Emadi, although he was forced to leave his country of origin, exile does not mean identifying with the place that has been left. Instead, he identifies with the place or location from which the experiences of exile are narrated. Emadi entered Finland as a refugee, while Spain was a destination he had selected himself. Before he arrived, nothing about Finland was familiar to him, but as a place of exile it became meaningful (Saresma 2019). He tries to explain his relationship with Finland to me, his Finnish interviewer:

My life in various countries was ... different... [you should know that] before I try to explain... my experience of Finland. Umm, I identify with my exile in Finland more than I identify with my experience of any other place. I don't know if I can explain it very clearly, but Finland [is important] to me. For example, I made one of my films here. It is a documentary, a full-length 
documentary on the life and poetry of Antonio Gamoneda, the great Spanish writer and poet. It's a kind of prose documentary, written in the form of a letter. The letter is narrated by me, speaking to Antonio, quoting him. When I am quoting him, I am in his life. But when I stand and write, speaking as a subject, the place that I narrate is Finland. I use Finnish lakes, I use Finnish islands, and my voice is in Finland, speaking.

Emadi also made another documentary in Mexico about the exile of Luis Cernuda. In it, he also uses Finland as his place of exile. So, when the narrator speaks, Finland is there. For him the narrator always stands in Finland.

For Emadi, then, it is not so much a question of exile from somewhere but exile as a present location or position from which current events are experienced and interpreted. In a sense, exile is for him an identity: "So, when I identify - I use the image of identity - when I identify with my own exile, I use Finland." He does it for different reasons. One is his love towards lakes and islands, since he feels himself as a kind of an island. "This metaphor of [man as an] island is very close to me." He also perceives Finland as a very melancholic country and himself as a melancholic person. Finland is for him the country of silences, and he feels himself very attached to silence, especially when he works. "With friends I do like conversation, speaking with them, but when it comes to love, I do not like to speak much. When I love somebody, I prefer to communicate in silence, because that's where real communication happens." (On the meaning of silence in Emadi's poetry, see Saresma 2019.)

You can send one hundred word-garrisons out into the street, still poetry lives in the silence between words

(from "The Narration of History within the Calendar of Betrayal", Standing on Earth, 2016:54)

Emadi explains furthermore:

There is ambience in Finland that I identify with, and I always miss it [when I am away]. When I am in Mexico, I am in another space, but, as my exile, I say that a part of me is there in Finland. It is very deeply inside me. Probably because I lived it and I survived it, with all the pains, I get to be attached to that story. Probably it's because of that, you know, once you have survived a brutal situation, you later somehow miss that situation. Many different, many complicated things happened for Finland to become the identification of my, the place of my exile.

In some sense Mohsen Emadi has found harmony in Finland. Elsewhere (Saresma 2019) I interpret the Yamsa of his poem as a location where all the meaningful chronotopes of his life amalgamate, where it is silent and peaceful. And yet Yamsa, the small municipality in central Finland, far from the wars and disturbances of Emadi's youth, embraces also the potential of destruction or at least of non-belonging and exclusion:

I passed all these borders inside myself, so I don't have the same sense of belonging you have. I belong to the Finns the same way that I belong to you, 
you know. Inside myself. But the problem is that most of the time Finns don't want me as their own.

Elsewhere, Emadi has discussed racism and othering, which he sees as emblematic for contemporary societies (Saresma 2019). These violent processes prevent individuals from encountering each other as individuals. Instead, they become members of a certain group and get valued (or de-valued) as such. For him reaching out for the essence or the meaning of a person or a poem is vital, and a true encounter becomes fundamental:

This is the question. I compare exile and translation. Translation of a poetry book or a novel is possible because there is the destination language. In translation, the necessity of touching one poem, one book, in another language is recognized. So, the necessity originates in the original art. But exile is not like that. The destination doesn't like you, it never asked for you. You are going there [uninvited].

In his idea of exile as home, Emadi is close to Said's (2001:185) idea of exile as "an intellectual and de-territorialized home", home as a relationship more than as a place, as in the next excerpt:

\author{
You were looking at me \\ and the rain was still raining \\ on your suitcases \\ and the shoes and the hats of the dead. \\ I kiss you and we exchange losses \\ (from Standing on Earth, p. 35)
}

\title{
8. Exile, nomadism, diaspora
}

Living in exile, Emadi states that he does not have a fatherland. His country of origin is something he has left behind for good. As a member of the Iranian diaspora, he is supposed to want to go back. As a nomad, he would return there eventually, only to leave again; his life would be continuous mobility between Iran and Spain, as it used to be - moving between these two fruitful areas to feed his poetic imagination. But exile changes the nomadic lifestyle.

Spain for me is more like home. I rarely felt out of home in Spain, because I experienced Spain as a part of my experience of Iran. When I went to Spain, I knew I would come back to Iran. It was normal. It was [before] the time Iran got removed from the map for me. The experience was kind of nomadic, in the normal nomadic way. Nothing like exile, it was a nomadic way of life. In the nomadic life, both of the places that you continually go to are your home. So, my life at that time was nomadic; I went to one place for winter and then another for summer, and both of the places were mine.

But this modern, cosmopolitan nomadism is not possible for him; it is not an option any more. Generally speaking, nomadism as a traditional way of life in Iran is dead or dying, as Ehlers (2011) suggests: "the economic basis and the habitat, 
the migrational patterns and the aims and goals of pastoral economy are changing or have already vanished". Nomadism as a historical arrangement may be vanishing in the globalizing urban culture, but perhaps exile in the sense in which Emadi uses the concept is 'new nomadism'. He has always felt the need to move, like the traditional nomads have moved. Yet being torn from his village of birth and his family was a violent experience. This entanglement of voluntary mobility and a certain rootlessness may be an incarnation of 'new nomadism' that Rosi Braidotti (1994) discusses or a 'modern nomad' that Ada Engebritsen (2017) refers to.

Whereas nomadism means moving between two places, exile for Emadi is a fruitful position outside nation states. Emadi is critical of the concept of diaspora since it presupposes the idea of having a home to return to, so perhaps the concept transnationalism would better describe his life. As a multi-lingual poet and translator, he is skeptical even about the idea of native language as one's home (Saresma 2019). Neither home nor native country are emotionally important points of identification for Emadi, but exile is both positive and important. Living in exile, he likes to think that the land of poetry is his home. For Emadi, poetry is a way to deal with his experiences of exile and non-belonging. It is a multilingual space where he can express himself in various ways to various audiences. The land of poetry is not excluding the same way as are some places with the Iranian diaspora. Mohsen expresses harsh critique of the concept of diaspora. Diaspora communities are like 'two sides to the coin':

Because when a culture isolates another culture, the isolated people don't just accept it, they also become colonized on the inside. So, you see, there are different colonies, different ghettoes forming inside the communities. And because the culture here never accepted them, you know, as their own, they turn inwards and only communicate with each other.

Emadi uses the concept of diaspora in a loose sense, mainly to refer to a group of emigrants that have powerful ties with their homeland, especially its culture, but perhaps also its politics (Brubaker 2006:2). The habit of sticking to what has been left behind makes him feel excluded, and he criticizes the cherishing of this cliquey, clannish kind of diaspora that he has met in various locations of exile. Similarly to France he found in the USA closed Iran communities: "When I went to Los Angeles, it was like just entering Iran, like going to Tehran." People were eating the same foods and had Iranian ways: they were listening to the same music people listen to in Tehran. All of them were Iranians meeting other Iranians, going out mainly with each other. Staying with the people will bring you in contact with just that culture, and they are very closely knit. These people marry among themselves and "there is always the same story, "ghetto, ghetto, ghetto". But Emadi does not feel at home among these people, instead he feels like he belongs to another species that doesn't want to mix with them.

His critical attitude towards the idealized togetherness of people living in diaspora is entangled with a certain estrangement from his alleged culture that Emadi suffers from when he meets members of the Iranian diaspora either in the 
US or in the metropolises of Europe. Again, he finds no cure to his existential exile from a community: in the following fragment of his poem, he describes how things happen without human intention, how we are thrown in the world, and the best we can do is to try to find a momentary salvation from encountering the other as an individual, not as a representative of any culture.

\author{
Snow falls without reason \\ and the poem written with a human intention \\ does not heal. \\ Kiss me! \\ (from Standing on Earth, p. 49)
}

\title{
9. Poet of exile?
}

Mohsen Emadi's refusal to become a member of the Iranian diaspora is exceptionally strong: "In the end, I no longer belong to Iran. I'm not Iranian the same way that many people can say 'I'm Iranian', because I don't identify with many parts of that culture. I am very critical towards it, the same way that I am critical towards myself. The process of criticizing myself and changing myself was at the same time a critique of my own culture."

Since he no longer identifies as Iranian, it becomes necessary to ask which nation Emadi would feel he belongs to, if any. And he asks himself: "So then, I'm not a Finn, or a Mexican, or s Spaniard. Okay, so who am I in the end?"

In asking these questions, Emadi shares resemblance with the Iraqi-born writer Hassan Blasim. Blasim, who lives in Tampere and Helsinki, Finland, has been categorized as a transnational writer "referring to border crossings and the fact that he cannot be located in one place only" (Löytty 2018:74). Like Blasim, Emad's place "in the transnational cartography of literature" (ibid.) is manifold; moreover, Emadi refuses to identify with any country, but he has to take a stand on this existential question. So, he has a utopian solution: he identifies with exile, he äis from exileä: "I realized that I have to identify with one thing, with my own exile. Exile is my country, in the end. It turned out to be the country for me. Because there is no border for it, you know. And I can receive everybody there, without any sort of anger or without any sort of fragmentation of its people. There is no place for racism in exile, there is no place for stereotypes there. So, one day I want to [answer the question], 'Where are you from?' with 'I am from exile'."

Emadi's thinking is also reminiscent of the statement of another writer and intellectual born in Iran, Hamid Dabashi:

I've been on the move all my life [---] These movements have not made me feel homeless or displaced me into a diaspora. I am not in exile, for, as Nima said, donyakhaneh-ye man ast. The world is my home (Davison and Muppidi 2011:5).

But unlike Dabashi, Emadi does emphasize that he is in exile, or, he belongs to exile. Based fundamentally in exile instead of any nation-state, much like Dabashi, 
who claims being above all a writer "embedded existentially in the world around me (ibid.)", Mohsen Emadi too lives a transnational, trans-continental life. As I have tried to describe, with the help of the interview excerpts and the fragments of his poetry, he has turned to forced mobility and the constant sense of nonbelonging as the driving force of his art.

Exile is not only bad or regrettable: many kinds of emotions, both difficult and positive, even thankfulness, are related to Emadi's experiences of exile, because "exile gave him the whole world", as he puts it in an interview (Author 2019). In his understanding and experience, exile as a voluntary act or position has lost its historical meaning, its "forced and immobile quality" as a banishment to or from a particular place (Hackl 2017:59).

More generally, too, as it is sometimes argued, exile has been transformed from a form of punishment into a respectable state (ibid.: 57) to the extent that the 'trope of exile' "became a 'potent metaphor' for the distinctive, the disjunctive and the alienated, particularly within cultural and literary studies" (Everett and Wagstaff 2004). Exile - especially literary exile - has even become a desirable position, an aestheticized metaphor (Hackl 2017:56). This even voluntary displacement of high culture and literary heroes sometimes becomes an ascetic project that may advance the image of an elevated and aestheticized 'class of exile' that is elite, cosmopolitan, intellectual and privileged (Lumsden 1999: 31-32).

Notwithstanding being a poet of exile, Emadi does not romanticize exile; he is familiar with the downsides of global mobility, such as othering, racism, and xenophobia (Saresma 2019). Yet, for him, mobility is a way of life, and he does not even dream of settling down, not to mention of returning to Iran. Due to his voluntary transnational nomadism and his experiences as a political refugee, his life story is the epitome of the many sides of both forced and chosen exile. Perhaps the dual position enables him to 'stand outside', as a loner (Said 1998), and from that position, to write poetry that tackles the question of exile as a manifold experience that is of growing importance in contemporary culture.

\section{Conclusion}

The questions related to mobility, nomadism, diaspora, and exile are constantly present in Emadi's poetry. His critique of the concept of diaspora and his refusal to romanticize exile contribute to the theoretical discussion on these themes. At the beginning of our interview, Mohsen Emadi explained that there are various dimensions - cultural, socio-political, and personal - that force or encourage people to leave a place. In the interview and in his poetry, he discusses all these. For him, then, exile is an experienced condition in the sense suggested by Andreas Hackl (ibid.:64): an "enduring aftermath of political displacement" that impacts both "political subjectivity, identity and mobility". In Emadi's case, exile resulted from "self-banishment because of [his] opposition to political regimes", fueled 
first by the inner coercion to leave his childhood environment and later, the political necessity of leaving Iran.

In Emadi's mobile way of life and in his critique of the practices of diaspora, what Hackl (ibid.: 65) calls the two 'faces of exile', namely, "the tension between cosmopolitanism and fixation, between mobility and confinement", are connected. This way, the "dichotomy between metaphors of "travel' and 'displacement"" are overcome. His life choices that I have elsewhere called the politics of dislocation (Saresma 2019) emphasize the need to move, not to settle down, not to long for return, but to dwell in the experience of exile instead. Exile as a condition of displacement, as Hackl (ibid.) puts it, goes "beyond the legal-political classifications of 'refugees' and 'immigrants". Exile is "conceptually compelling" (ibid.) but as Emadi demonstrates in his poetry and through his mobile life, it is possible to surpass any external definitions and to be both a cosmopolitan and a refugee, a nomad and an exile. It is possible to transcend behavioral norms - such as those connected to living a life in diaspora and cherishing the habits and practices of the country of origin, only waiting to return home - and live and write as a poet of exile, to draw from the experience of displacement and instead of belonging to a national state, to belong to exile itself.

His dream, which might be a nightmare to some, is described in the last verses of the last poem in the book Standing on Earth. Here, the poet of exile is imagining a place that does not exist in any specific country, but on the soil of our shared earth, where there are no more tears, no more ghosts, no more agony. This shared earth that we stand on is the location of our joint dreams, hopes, and faith:

The wind dishevels her hair even more.

She wipes away her tears and smiles.

The ghosts escape.

We are standing on earth,

imagining another paradise

(from Standing on Earth, p. 88)

\section{Acknowledgements}

This article is part of project Intersecting Mobilities, funded by Kone foundation. Writing was also supported by the Academy of Finland under grants Crossing Borders (decision number 308521) and CRISES (decision number 311877).

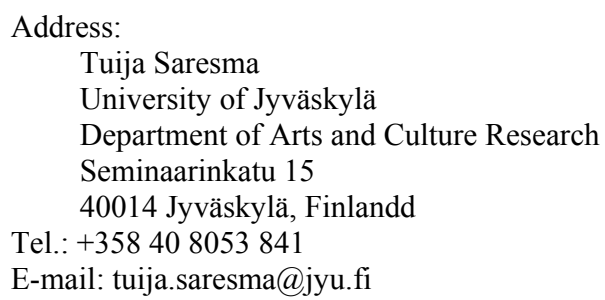




\section{References}

Braidotti, Rosi (1994) Nomadic subjects: embodiment and sexual difference in contemporary feminist theory. New York: Columbia University Press.

Brubaker, Rogers (2005) “The 'diaspora' diaspora". Ethnic and Racial Studies, 28:1-19, DOI: $10.1080 / 0141987042000289997$.

Dabashi, Hamid (2011) "Shi'ism as paradox". In Andrew Davison and Himadeep Muppidi, eds. The world is my home: a Hamid Dabashi reader, 57-65. New Brunswick and London: Transaction Publishers.

Dabashi, Hamid (2011) "On nations without borders". In Andrew Davison and Himadeep Muppidi, eds. The world is my home: a Hamid Dabashi reader, 121-144. New Brunswick and London: Transaction Publishers.

Davison, Andrew and Himadeep Muppidi (2011) "Introduction". In Andrew Davison and Himadeep Muppidi, eds. The world is my home: a Hamid Dabashi reader, 1-16. New Brunswick and London: Transaction Publishers.

Dufoix, Stéphane (2008) Diasporas. Oakland, CA: University of California Press.

Ehlers, Eckart (2011) "Nomadism". EncyclopaediaIranica. Available online at $<\mathrm{http}: / / \mathrm{www}$. iranicaonline.org/articles/nomadism>. Accessed on_19.11. 2018.

Emadi, Mohsen (2016) Standing on Earth. Transl. from the Persian by Lyn Coffin. Los Angeles, CA: Phoneme Media.

Engebritsen, Ada Ingrid (2017) "Key figure of mobility: the nomad". Social Anthropology 25, 1, 42-54.

Everett, Wendy and Peter Wagstaff (2004) Cultures of exile: images of displacement. Oxford: Berghahn

Hackl, Andreas (2017) "Key figure of mobility: the exile”. Social Anthropology 25, 1, 55-68.

Lumsden, David P. (1999) "Broken lives? Reflections on the anthropology of exile and repair". Refuge: Canada's Journal on Refugees 18, 4, 30-39.

Löytty, Olli (2017) “Welcome to Finnish literature! Hassan Blasim and the politics of belonging”. In Katrien De Graeve, Riikka Rossi, and Katariina Mäkinen, eds. Citizenships under construction: affects, politics and practices, 67-82. (COLLeGIUM: Studies across Disciplines in the Humanities and Social Sciences, 23.) Helsinki: Helsinki Collegium for Advanced Studies. Available online at $<\mathrm{http} / /$ hdl.handle.net/10138/228630>. Accessed on 30.10.2018.

Malkki, Liisa (1995) "Refugees and exile: from 'refugee studies' to the national order of things". Annual Review of Anthropology 24, 495-523.

Perälä, Annuand Mari K. Niemi (2018) "Asylum seekers arrived, elites occupied the air: topics and interviewees in YLE's magazine programmes during the 'asylum seeker crisis"'. Nordicom Review (ahead of print), 1-15. DOI: 10.2478/nor-2018-0013.

Peteet, J. (2007) "Problematizing a Palestinian diaspora". International Journal of Middle East Studies39, 624-646.

Rastas, Anna (2014) "Talking back: voices from the African diaspora in Finland". In Michael McEachrane, ed. Afro-Nordic landscapes: equality and race in Northern Europe, 187-207. Routledge: New York.

Said, Edward (1978) Orientalism. New York: Pantheon.

Said, Edward (1994) Culture and imperialism. London: Vintage.

Said, Edward (1998) "Between worlds: Edward Said makes sense of his life". London Review of Books 20, 3-7.

Said, Edward (2001) Reflections on exile, and other literary and cultural essays. London: Granta.

Saresma, Tuija (2016) Intersecting mobilities: narratives of mobility and belonging. Available online at $\quad<\mathrm{http}: / / \mathrm{www}$.intersectingmobilities.org/intersecting-mobilities-narratives-of-migrationand-belonging/>. Accessed on 2.11.2018.

Saresma, Tuija (2019) "Hajauttamisen ja poissaolon politiikkaa MohsenEmadin elämässä ja runossa YAMSA - a tribute to absence". In Kaisa Hiltunen and Nina Sääskilahti, eds.Kuulumisen reittejä taiteessa, 201-228. Turku: Eetos.

Vaughan-Williams, Nick (2015) Europe's border crisis: biopolitical security and beyond. Oxford: Oxford University Press. 
